\title{
Personality Traits and Positive/Negative Affects: An Analysis of Meaning in Life among Adults
}

\section{Şerife $\mid$ şı $^{\mathrm{a}}$}

Gazi University

\author{
Nazife Üzbe \\ Gazi University
}

\begin{abstract}
This study examines the impact of positive and negative affects and personality traits on meaning in life in an adult population. The sample consisted of 335 subjects: 190 females and 145 males, and a Meaning in Life Questionnaire (MLQ), positive and negative schedule (PANAS), and adjective-based personality scale (ABPT) were used in the research. The data were analyzed on a one-way analysis of variance (ANOVA) as well as a Pearson product moment correlation and hierarchical multiple regression analysis. According to the findings of the study, early adults' search for meaning in life was higher than either middle-aged adults or older adults. Positive affect, extraversion, openness to experiences, agreeableness, and conscientiousness correlated with both the presence of meaning in life and the subject's search for meaning in life. In addition, the results of the Pearson correlation analysis indicated that presence of meaning in life had a significant negative correlation with negative affect and neuroticism. According to the results of multiple regression analysis, presence of meaning in life was predicted by openness to experiences, neuroticism, and positive affect, while the search for meaning in life was predicted by extraversion and negative affect.
\end{abstract}

Keywords: Meaning in life $\bullet$ Positive/negative affectations $\bullet$ Personality traits $\bullet$ Adults $\bullet$ Positive psychology

a Corresponding author

Assoc. Prof. Serife Ișık (PhD), Department of Guidance and Psychological Counseling, Gazi University, Ankara, Turkey

Research areas: Positive psychology; Comprehensive school counseling programs

Email: terziserifedyahoo.com

b Nazife Üzbe, Department of Guidance and Psychological Counseling, Gazi University, Ankara, Turkey Email: nazifeuzbeldyahoo.com 
Meaning in life is an evolving concept rooted in existential psychology and addressed frequently in studies related to modern positive psychology. Positive psychology considers meaning in life as an element of satisfaction and happiness (Park, Peterson, \& Ruch, 2009; Peterson \& Seligman, 2004). The definition of meaning in life has varied considerably due to its very nature. Frankl (2010), for example, defines meaning in life as a basic motive that every person innately possesses. Meaning in life then, as a concept, is not associated with certain subjects but all life events. Frankl suggests that every experience in life is related to meaning at varying levels, and thus should be explored. According to Baumeister (1991), meaning in life refers to lasting affects that help to build self-worth in a person's life. Wong (2010) defines the structure and functions of meaning in life as purpose, understanding, responsible action, and enjoyment/evaluation and argues that it encompasses motivational (purpose), cognitive (understanding), ethical/moral (responsibility), and affective processes (enjoyment).

Meaning in life is also described as a fundamental motivation containing individual goals and beliefs that reflects people's general perception of and attitude toward life, themselves, and others around them (Park, 2010; Steger, 2009). Steger et al. (2010) emphasizes that meaning in life should be analyzed through two other concepts: the search for meaning in life and the presence of meaning in life. The search for meaning in life is depicted as people's will to build or foster significance, meaning, and purpose, while the presence of meaning refers to a state of being in which people fully realize themselves and the world, find their unique purpose, and endeavor to achieve something important (Steger et al., 2010). While the presence of meaning in life represents an invaluable result, search for meaning in life points to a significant process (Steger, Fraizer, Oishi, \& Kaler, 2006). Based on these depictions, meaning in life should not be viewed as a fixed concept, but rather a dynamic one that transforms according to experience.

According to King, Hicks, Krull, and Del Gaiso (2006), individuals refer to their affects as sources of information when they attempt to answer whether their lives are meaningful. When questioned about the quality of their lives, people evaluate their purpose based on their existing affects rather than considering all possible pieces of information (Schwarz \& Clore, 1996; Schwarz \& Strack, 1999). Studies on affects (Gençöz, 2000; Joiner, Catanzaro, \& Laurent, 1996; Watson, Clark,
\& Tellegen, 1988) illustrate that affects involve two separable fundamental components: one negative and one positive. Bradburn (1969) first addressed positive affect and negative affect and described happiness as the balance between the two. While a positive affect denotes the combination of willingness, joviality, mental alertness, and determination, a negative affect represents a wide range of unpleasant moods such as sadness, fear, anxiety, rage, and sense of guilt (Watson, 1988; Watson \& Pennebaker, 1989). According to Gençöz (2000), a positive affect is "active pleasure and joy one finds in life," and a negative affect is "the activation of unpleasant affects such as stress, fear, and anger." Studies about the concept of meaning in life and personal affects (King et al., 2006; King \& Hicks, 2009) suggest that positive affects provide are the primary contributors to the perception of meaning in life, and that situations characterized by positive affects could serve as a "natural habitat" for meaning in life. They also imply that negative affects are triggered when individuals' needs for meaning in life are not satisfied (Maddi, 1970; Pan, Wong, Joubert, \& Chan, 2007).

Individuals have meaningful experiences throughout the majority of their lives, and these remarkably shape their well-being (Lavigne, Hofman, Ring, Ryder, \& Woodward, 2013). In recent years, unique personal traits and, more specifically, the Big Five personality traits, have been incorporated into studies focused on the concept of meaning in life (Halama, 2005; Henningsgaard \& Arnau, 2008; Mascaro \& Rosen, 2005). According to the Five Factor Model, which is an umbrella model for different perspectives on personality, the five main personality traits are neuroticism, extraversion, openness to experience, conscientiousness, and agreeableness (Bacanl, İlhan, \& Aslan, 2009). Neuroticism signifies the tendency to experience negative affects such as guilt, nervousness, depression, and fear, and involves behaviors such as lack of self-acceptance, perfectionism, and not being open to criticism (Costa \& McCrae, 1995). Extroversion denotes how sociable, active, determined, talkative, sensationseeking, and outgoing individuals are (Bono, Boles, Judge, \& Lauver, 2002), while openness to experience represents the tendency to attend intellectual activities and being receptive to new emotions and thoughts. Openness to experience is, in a sense, associated with intellectual interest, esthetic sensitivity, imagination, flexibility, and unconventional attitudes (Chamorro-Premuzic, 2007). Conscientiousness is related to leadership, self-discipline, goal-orientation, self-sufficiency, 
orderliness, sense of mission, productivity, and determination (Costa \& McCrae, 1995), while agreeableness is defined as being reliable, agreeable, straight-forward, self-giving, and modest (Bono et al., 2002). Current conceptualizations associated with the concept of meaning in life present different personality traits; for instance, meaning in life is negatively correlated with neuroticism (Halama, 2005; Moomal, 1999) but positively correlated with extroversion, conscientiousness, and agreeableness (Lavigne et al., 2013; Mascaro \& Rosen, 2005; Steger, Kashdan, Sullivan, \& Lorentz, 2008). In the light of these theoretical insights, it can be asserted that personality traits and positive/negative affects are significant variables in interpreting meaning in life.

In positive psychology, which highlights that the science of psychology should aim to ensure more satisfying and happier lives for "normal" individuals, meaning in life is considered as one of the indicators of well-being (Debats, Drosst, \& Hansen, 1995; Fry, 2000; Zika \& Chamberlain, 1992). This study explores the concept of meaning in life that contributes to individual levels of wellbeing due to its significance in preventive psychiatry. It is important to address positive psychology and its concepts, which emerged as a result of the understanding that mental health cannot be explained only by a lack of psychopathology within the scope of Turkish culture. There are studies on meaning in life in Turkey as well (Demirbaş, 2010; Şahin, Aydın, Sarı, Kaya, \& Pala, 2012; Terzi, 2013; Terzi, Ergüner Tekinalp, \& Leuwerke, 2011), but they are very limited. Thus, there is a need for empirical studies that will help explore the depths of the concept of meaning in life, particularly through the lens of Turkish culture, which have heretofore been conducted mostly among university students. This study targeted an adult survey population to analyze the relationship between meaning in life, personality traits, and positive/negative affects among adults at different developmental stages.

\section{Method}

\section{Research Design}

The current study is based on a correlational research model that examines the relationship among more than one variable without any intervention. This correlational research is divided into two parts: exploratory and predictive. In the exploratory correlational design, an important event is understood by analyzing a relationship among variables, while the predictive correlational design is used to predict certain outcomes between one variable and another (criterion variable) that serves as the predictor. While the predictor variable is used to make a forecast, the criterion variable is the anticipated outcome (Fraenkel \& Wallen, 2006). In the present study, meaning in life as a criterion variable, positive affect and negative affect, and personality traits as predictor variables are defined.

\section{Participants}

The convenience sampling method was used in the research. The total sample size was 335, composed of 190 females and 145 males. Participants were divided into three groups according to their age range: young adults $(18-34 ; n=128)$, middle-aged adults (35-64; $n=141$ ), and older adults (older than 65 age; $n=66$ ).

\section{Instruments}

Meaning in Life Questionnaire: The Meaning in Life Questionnaire (MLQ) was developed by Steger et al. (2006) and examines the presence of meaning in life (MLQ-P) and the search for meaning in life (MLQ-S) using 10 items rated on a 7-point Likert scale ranging from "Absolutely true" to "Absolutely untrue." The Turkish adaptation of the scale was done by Terzi et al. (2011). In order to determine the construct validity of MLQ, an exploratory and confirmatory factor analysis was conducted. The factor analysis resulted in two factor loading elements, which ranged from 0.52 to 0.79 for MLQ-P, and 0.62 to 0.81 for MLQ-S. Similarly, the results of the confirmatory factor analysis indicated that the model was appropriate. The goodness of fit index values of the model were RMSEA $=0.07$, GFI $=0.94$; AGFI $=0.90 ; \mathrm{NFI}=0.89 ; \mathrm{CFI}=0.90 ; \mathrm{IFI}=$ 0.92 . These values show that the structural model of MLQ, which consists of two factors, was well-fit to the Turkish culture. For criterion related to validity of the Turkish version of the scale, MLQ-P presented a correlation of 0.58 on the Life Satisfaction Scale; while the MLQ-S correlation was found to be 0.25 . Cronbach alpha internal consistency coefficient was found as 0.75 for MLQ-P and 0.82 for MLQ-S.

Positive and Negative Affect Schedule: Positive and Negative Affect Schedule (PANAS), originally developed by Watson et al. (1988), measures how an individual feels at a certain time (e.g., over the past week, day, or at that moment). The PANAS is a 20-item self-reported questionnaire designed to measure positive, and negative affects, and items 
are rated on a five-point Likert-scale $(1=$ "very slightly or not at all" to $5=$ "extremely"). There are 10 items in each of the positive affect (PA) and negative affect (NA) scales. The Turkish adaptation of the scale was done by Gençöz (2000) and in this study revealed an internal consistency reliability of .83 for the PA, .86 for the NA, and a test-retest reliability of .40 for the PA and .54 for the NA. For criterion-related validity of the Turkish version of the scale, positive affect presented correlations of -.48 and -.22 with Beck Depression Inventory and Beck Anxiety Inventory, respectively; while Negative Affect correlations were found to be .51 and .47, respectively for these inventories.

Adjective-Based Personality Scale: Developed by Bacanlı et al. (2009), the Adjective-Based Personality Scale (ABPT) is a Likert-type scale consisting of 40 pairs of adjectives that can be graded between 1 and 7. ABPT is composed of five dimensions: extroversion, agreeableness, conscientiousness, emotional stability/neuroticism, and openness to experience. These five dimensions explain $52.63 \%$ of the variance of ABPT. The factor loadings of the five dimensions vary between .367 and0 .793 . Test-retest reliability coefficient was found to be .85 for extroversion, .86 for agreeableness, .71 for conscientiousness, .85 for emotional instability/ neuroticism, and .68 for openness to experience. Meanwhile, the Cronbach alpha coefficient was found to be .89 for extroversion, .87 for agreeableness, .88 for conscientiousness, .73 for emotional instability/neuroticism, and .80 for openness to experience.

\section{Data Analysis}

Data analysis was conducted using an SPSS program. In addition, as Pearson product moment correlation was used to determine the relationship between meaning in life, positive affect, negative affect, and personality traits. Then, in order to determine if the meaning in life differed according to age groups, a one-way ANOVA was used. Finally, a hierarchical multiple regression analysis was performed in order to examine the impact of positive affect, negative affect, and personality traits on the meaning in life.

As hierarchical regression analysis is a multivariate statistical method, the first hypothesis of the analysis was evaluated, controlled for any missing data in the data set There were no data that showed multivariate values calculated by means of univariate Mahalanobis distance and $z$-score values determined by boxplot. Histograms of variables were analyzed for assumption of normality. As for the coefficients of Skewness and Kurtosis that were separately calculated, the coefficients were observed to have varied between -1 and +1 , and not to have excessively deviated from the standard. Coefficients of correlation between variables were calculated to check for multi-collinearity and singularity between variables, significant correlation coefficients varied between .11 and .60 ; thus, no multi-collinearity was determined. The Durbin-Watson statistic was calculated to determine whether there was any autocorrelation between variables; the resulting statistic (1.441-1.768) did not show any autocorrelation in the data set.

\section{Results}

In order to test whether the sub-dimensions of meaning in life differed among the age groups included in the study, a one-way ANOVA was employed. The analysis results are shown in Table 1.

\begin{tabular}{|c|c|c|c|c|c|}
\hline \multicolumn{6}{|c|}{$\begin{array}{l}\text { Table } 1 \\
\text { ANOVA Results of Presence of Meaning in Life }\end{array}$} \\
\hline & $\begin{array}{l}\text { Source of } \\
\text { Variance }\end{array}$ & $\begin{array}{l}\text { Sum of the } \\
\text { Squares }\end{array}$ & $S D$ & $F$ & $\begin{array}{l}\text { Significant } \\
\text { Difference }\end{array}$ \\
\hline \multirow{3}{*}{$\begin{array}{l}\text { Pres- } \\
\text { ence of } \\
\text { Meaning } \\
\text { in Life }\end{array}$} & $\begin{array}{l}\text { Between } \\
\text { Groups }\end{array}$ & 67.871 & 2 & \multirow{3}{*}{1.691} & \\
\hline & $\begin{array}{l}\text { Within } \\
\text { Groups }\end{array}$ & 6661.610 & 332 & & \\
\hline & Total & 6729.481 & 334 & & \\
\hline \multirow{3}{*}{$\begin{array}{l}\text { Search } \\
\text { for } \\
\text { Meaning } \\
\text { in Life }\end{array}$} & $\begin{array}{l}\text { Between } \\
\text { Groups }\end{array}$ & 1111.332 & 2 & \multirow{3}{*}{$7.237^{*}$} & \multirow{3}{*}{$1-2,1-3$} \\
\hline & $\begin{array}{l}\text { Within } \\
\text { Groups }\end{array}$ & 25492.487 & 332 & & \\
\hline & Total & 26603.819 & 334 & & \\
\hline
\end{tabular}

Based on this analysis, there was a significant difference among age groups regarding the search for meaning in life $\left(F_{(2,332)}=7.237, p<.05\right)$. To test among which groups there was the most marked difference, an LSD multiple comparison test was used. According to the results of the LSD test, young adults' search for meaning in life scores $(\bar{X}$ $=22.83, S=8.43)$ were higher than either middleaged adults $(\bar{X}=20.62, S=8.95)$ or older adults $(\bar{X}$ $=17.83, S=8.96$ ).

A Pearson product moment correlation was used to determine the relationship between presence of meaning in life and search for meaning in life with positive affect, negative affect, and personality traits. Table 2 shows the correlations among the variables. 
Table 2

Variables' Inter-correlations

\begin{tabular}{|c|c|c|c|c|c|c|c|c|c|}
\hline & 1 & 2 & 3 & 4 & 5 & 6 & 7 & 8 & 9 \\
\hline 1. Positive affect & 1.000 & & & & & & & & \\
\hline 2. Negative affect & -0.10 & 1.000 & & & & & & & \\
\hline 3. Neuroticsm & $-0.13^{*}$ & $0.48^{* *}$ & 1.000 & & & & & & \\
\hline 4. Extraversion & $0.50^{\star *}$ & $-0.16^{\star *}$ & $-0.13^{*}$ & 1.000 & & & & & \\
\hline 5. Openness to experiences & $0.50^{\star *}$ & $-0.16^{\star *}$ & $-0.13^{*}$ & $0.69^{* *}$ & 1.000 & & & & \\
\hline 6. Agreeableness & $0.19^{\star *}$ & $-0.21^{\star *}$ & $-0.27^{\star *}$ & $0.40^{* *}$ & $0.40^{* *}$ & 1.000 & & & \\
\hline 7. Conscientiousness & $0.42^{\star *}$ & $-0.18^{\star *}$ & -0.05 & $0.47^{\star *}$ & $0.47^{\star *}$ & $0.45^{\star *}$ & 1.000 & & \\
\hline 8. Presence of meaning in life & $0.29^{\star *}$ & $-0.19^{* *}$ & $-0.24^{\star *}$ & $0.30^{* *}$ & $0.30^{* *}$ & $0.20^{* *}$ & $0.24^{\star *}$ & 1.000 & \\
\hline 9. Search for meaning in life & $0.33^{\star *}$ & $0.11^{*}$ & 0.07 & $0.37^{\star *}$ & $0.37^{\star *}$ & $0.16^{* *}$ & $0.22^{\star *}$ & $0.11^{*}$ & 1.000 \\
\hline
\end{tabular}

As seen in Table 2, a significant positive correlation was found between presence of meaning in life and positive affect $(r=.29, p<.01)$, as well as the extraversion $(r=.30, p<.01)$, openness to experiences $(r=.30, p<.01)$, agreeableness $(r=$ $.20, p<.01)$, conscientiousness $(r=.24, p<.01)$ sub-dimensions of personality traits. A significant negative correlation was found between presence of meaning in life and negative affect $(r=-.19, p$ $<.01)$ and the neuroticism $(r=-.24, p<.01)$ subdimension of personality traits. Results indicate that a there is a significant positive correlation between search for meaning in life and positive affect $(r=$ $.33, p<.01)$, negative affect $(r=.11, p<.05)$, and the extraversion $(r=.37, p<.01)$, openness to experiences $(r=.37, p<.01)$, agreeableness $(r=.16$, $p<.01)$, conscientiousness $(r=.22, p<.01)$ subdimensions of personality traits.

Hierarchical multiple regression analysis was performed to predict meaning in life by positive affect, negative affect, and personality traits. Tables 3 and 4 present summary statistics for the hierarchical multiple regression for predicting presence of meaning in life and search for meaning in life, respectively.

As seen in Table 3, there are three significant models that explain the presence of meaning in life. Model 1 consists of the openness to experiences sub- dimension of personality traits, which accounted for $9 \%$ of the variance in presence of meaning in life, and was found to be a positive predictor of presence of meaning in life $(\beta=.30, t=5.74, p<.01)$. Results indicate that openness to experiences and neuroticism (Model 2) explains 13\% of the variance in presence of meaning in life. Neuroticism entered into the equation in Model 2 that contributed to $4 \%$ of explained variance, and neuroticism was found to be a negative predictor of presence of meaning in life $(\beta=-.20, t=-3.98, p<.01)$. Finally, openness to experiences, neuroticism, and positive affect were entered into the equation (Model 3) and explain $15 \%$ of the variance in presence of meaning in life. Positive affect contributed to $2 \%$ of explained variance, and positive affect was found to be a positive predictor of presence of meaning in life $(\beta$ $=.17, t=3.04, p<.01)$.

The results of the regression analysis are also presented in Table 4, and it can be seen that two significant models explain the search for meaning in life. Model 1 consists of openness to experiences, which accounted for $14 \%$ of the variance in search for meaning in life, and it was found to be a positive predictor $(\beta=.37, t=7.42, p<.01)$. Openness to experiences and neuroticism (Model 2) explain $17 \%$ of the variance in search for meaning in life. Neuroticism entered into the equation in Model 2

Table 3

Summary of Hierarchical Multiple Regression Analysis for Presence of Meaning in Life

\begin{tabular}{|c|c|c|c|c|c|c|c|}
\hline Model & Variable & $R$ & $R^{2}$ & $R^{2}$ adj. & S.E. & $\beta$ & $t$ \\
\hline \multirow[t]{3}{*}{1} & (Constant) & 0.300 & 0.09 & 0.087 & 0.952 & & \\
\hline & Openness to experiences & & & & & 0.30 & $5.739^{* *}$ \\
\hline & (Constant) & 0.362 & 0.13 & 0.126 & 1.294 & & \\
\hline \multirow[t]{2}{*}{2} & Openness to experiences & & & & & 0.27 & $5.289^{* *}$ \\
\hline & Neuroticism & & & & & -0.20 & $-3.976^{* *}$ \\
\hline \multirow{4}{*}{3} & (Constant) & 0.394 & 0.15 & 0.147 & 1.400 & & \\
\hline & Openness to experiences & & & & & 0.18 & $3.163^{* *}$ \\
\hline & Neuroticism & & & & & -0.19 & $-3.782^{* *}$ \\
\hline & Positive affect & & & & & 0.17 & $3.039^{* *}$ \\
\hline
\end{tabular}




\begin{tabular}{|c|c|c|c|c|c|c|c|}
\hline Model & Variable & $R$ & $R^{2}$ & $R^{2}$ adj. & S.E & $\beta$ & $t$ \\
\hline \multirow[t]{3}{*}{1} & (Constant) & 0.377 & 0.14 & 0.139 & 1.837 & & \\
\hline & Openness to experiences & & & & & 0.37 & $7.422^{* *}$ \\
\hline & (Constant) & 0.415 & 0.17 & 0.168 & 2.509 & & \\
\hline \multirow[t]{2}{*}{2} & Openness to experiences & & & & & 0.40 & $8.010^{* *}$ \\
\hline & Negative affect & & & & & 0.17 & $3.507^{* *}$ \\
\hline
\end{tabular}

and contributed to $3 \%$ of explained variance, as well as being found to be a positive predictor of search for meaning in life $(\beta=.17, t=3.51, p<.01)$.

\section{Discussion}

This study examined the concept of meaning in life according to developmental stages, and concluded that the presence of meaning in life does not vary according to age. This finding is supported by similar studies conducted among both young and old adults in relevant literature (Prager, 1997a, 1997b; Reker \& Fry, 2003). As part of this concept, meaning is regarded as a phenomenon in which individuals actively create every living condition, rather than being a fixed phenomenon out of people's control (Yalom, 1980). Thus, individuals endeavor to make the most of their lives, make sense of their experiences, and create their purpose of life throughout every stage. On the other hand, purposes of life have a crucial importance to people's meaning in life (Baird, 1985; Klinger, 1977). Individuals find meaning in life when they create purposes that render their lives valuable, and they form purposes during every stage of life in different areas (King, Richards, \& Stemmerich, 1998). When, in this context, meaning in life is evaluated together with purpose of life, it is possible to expect that the presence of meaning in life does not vary according to age.

Another finding of this study is that the personality traits of openness to experience and neuroticism, as well as positive affects, predict the presence of meaning in life. This aligns with relevant literature that reveals a positive correlation between openness to experience and the presence of meaning in life (Halama \& Dedova, 2007; Schnell \& Becker, 2006); and a negative correlation between neuroticism and the presence of meaning in life (Francis \& Hills, 2008; Halama, 2005; Halama \& Dedova, 2007; Mascaro \& Rosen, 2005). Openness to experience as a personality trait encompasses interest, curiosity, openmindedness, creativity, and receptiveness to change. Individuals with high levels of openness to experience are considered to generate new ideas, as well as be adventurous and productive (Costa \& McCrae, 1995). Battista and Almond (1973) suggest that the presence of meaning in life is closely related to rendering life comprehensible, achieving one's goals, and realizing one's potential. According to Frankl (2010), creating or achieving something important and being open to experiences form the core of meaning in life. Thus, it is significant that openness to experience as a personality trait strongly predicts the presence of meaning in life. Neuroticism, on the other hand, involves depression, anxiety, frequent emotional ups and downs, unease, and discomfort (Bacanlı et al., 2009). Findings in the relevant literature negatively correlate meaning in life with depressive symptoms (Mascaro \& Rosen, 2005; Westerhof \& Bohlmeijer, 2004) and anxiety (Ruffin, 1984). Given that individuals who find their lives meaningful perceive their lives as being satisfactory (Jia-Yang, Wong, Joubert, Lai, \& Wan, 2008; Kashdan \& Steger, 2007), a negative correlation between neuroticism and the presence of meaning in life is not inexplicable. This study also found that positive affect predicts the presence of meaning in life, as do similar studies (Hicks \& King, 2007; King et al., 2006; King \& Hicks, 2009). Positive affect influences cognition in a way that eases the nature of meaning and assists in the exploration of meaning. Fredrickson's (2001) Broaden and Build Theory suggests that positive affect leads to expanded attention; thus, it helps individuals see the bigger picture by rapidly screening their environments. According to Isen (1999), positive affect contributes to creative problem-solving, and encourages individuals to be more open to processing information. Carver and Scheier (1990) note that, thanks to positive affect, individuals are satisfied with the progress they make toward their goals. Positive affect demonstrates that individuals lead their lives with purpose. From this perspective, positive affects reinforce the presence of meaning in life.

This study concludes that the search for meaning in life varies according to developmental stage but remains a constant underlying factor. Findings suggest that compared to individuals in mid-tolate adulthood, those in early adulthood achieved higher scores in the search for meaning in life. The review of literature did not reveal any specific study 
that either supported or disproved this finding. Developmental theories define exploring life as an element of young adults' developmental needs that shape their identities as well as their professional and social roles (Arnett, 2000; Erikson, 1968). Early adulthood is a life phase filled with opportunities for individuals to expose their potential selves. Young adults make plans in various areas, and they expect, at very high levels, to realize these plans (Arnett, 2000). These characteristics highlighted in developmental theories explain higher levels in the search for meaning in life among young adults compared to middle-aged and older adults.

This study also found that openness to experience as a personality trait and negative affects predict the search for meaning in life. Findings of relevant studies establish a positive correlation between openness to experience and the search for meaning in life (Steger et al., 2008), and suggest that negative affects are triggered when the need for meaning in life is not satisfied (Maddi, 1970; Pan et al., 2007). Individuals who are open to experience tend to gain new experiences, identify themselves as unique, and are eager to learn and be open-minded; thus, it is expected that they are on a quest for meaning in life, which is defined as the willingness to create or enhance meaning and purpose of life, and to attend activities that serve these purposes. Another variable that shapes the search for meaning in life is negative affect. According to Steger et al. (2008), individuals who are disappointed are dissatisfied with their lives, have lost control, and are not happy in their relationships, are more apt to search for meaning more in life. Frankl (2010) argues that the search for meaning in life leads to internal tension, adding that this is a pre-condition for psychological health. In logotherapy, humans are not in a tensionfree state of balance; rather, they need to strive for a worthy purpose. They experience negative affects such as anxiety, stress, and boredom in this process (Altıntaş \& Gültekin, 2005). Negative affect generally indicates that there is a problem, and that it should be eradicated or attenuated (Schwarz \& Clore, 1996). From this perspective, a positive correlation between the search for meaning in life and negative affects is notable.

This study produced significant findings; however, it has certain restrictions as well. Whether outcomes of the study were independent of social desirability or not was not tested. Levels of depression and anxiety among participants were not measured, and these variables were not used as control variables. These limitations should be considered while evaluating the results. In sum, this study concludes that personality traits and positive/negative affects influence meaning in life, and these findings are in line with those of the relevant previous studies, and that meaning in life varies according to developmental stage. Meaning in life is complicated due to its very nature; thus, future studies should analyze meaning in life in terms of social relations, arts (e.g., music, drawing, and creativity), and in individual terms addressing religion, spirituality, self, and life events. The relationship between experiences of meaning in life and mental health is considered to be bidirectional. For instance, do individuals find their life experiences meaningful because they feel well, or do they feel well because their life experiences are meaningful? Future studies should reveal the dynamic relationship between meaning in life and mental health by means of qualitative research. Finally, based on the outcome that young adults are more involved in the quest for meaning in life, it will be significant to conduct experimental studies on meaning in life among young adults and prepare compatible education programs. 


\section{References}

Altıntaş, E., \& Gültekin, M. (2005). Psikolojik danışma kuramları (2nd ed.). İstanbul: Alfa Akademi.

Arnett, J. J. (2000). Emerging adulthood: A theory of development from the late teens through the twenties. American Psychologist, 55, 469-480.

Bacanl, H., İlhan, T., \& Aslan, S. (2009). Beș Faktör Kișilik Kuramına dayalı bir kişilik ölçeğinin geliştirilmesi: Sıfatlara Dayalı Kişilik Testi. Türk Eğitim Bilimleri Dergisi, 7(2), 261-279.

Baird, R. A. (1985). Meaning in life: Discovered or created? Journal of Religion and Health, 24(2), 117-124.

Battista, J., \& Almond, R. (1973). The development of meaning in life. Journal for the Study of Interpersonal Processes, 36(4), 409-427.

Baumeister, R. F. (1991). Meanings of life. New York, NY: Guilford.

Bono, J. E., Boles, T. L., Judge, T. A., \& Lauver, K. J. (2002). The role of personality in task and relationship conflict. Journal of Personality, 70(3), 1311-1344.

Bradburn, N. (1969). The structure of psychological wellbeing. Chicago, IL: Aldine.

Carver, C. S., \& Scheier, M. F. (1990). Origins and functions of positive and negative affect: A control-process view. Psychological Bulletin, 97, 19-35.

Chamorro-Premuzic, T. (2007). Personality and individual differences. Oxford: Wiley-Blackwell.

Costa, P. T., \& McCrae, R. R. (1995). Domains and facets: Hierarchical personality assessment using the revised neo personality inventory. Journal of Personality Assessment, 64(1), 21-50.

Debats, D. L., Drost, J., \& Hansen, P. (1995). Experiences of meaning in life: A combined qualitative and quantitative approach. British Journal of Psychology, 86, 359-375.

Demirbaş, N. (2010) Yaşamda anlam ve yılmazlık (Master's thesis, Hacettepe University, Ankara, Turkey). Retrieved from https://tez.yok.gov.tr/UlusalTezMerkezi

Erikson, E. H. (1968). Identity: Youth and crisis. New York, NY: Norton.

Fraenkel, J. R., \& Wallen, N. E. (2006). How to design and evaluate research in education (6th ed.). New York, NY: McGraw-Hill.

Francis, L. J., \& Hills, P. R. (2008). The development of the Meaning in Life Index (MILI) and its relationship with personality and religious behaviours and beliefs among UK undergraduate students. Mental Health, Religion \& Culture, $11,211-220$.

Frankl, V. E. (2010). İnsanın anlam arayışı (trans. S. Budak). İstanbul: Okuyan Us Yayınları.

Fredrickson, B. L. (2001). The role of positive emotions in positive psychology: The broaden-and-build theory of positive emotions. American Psychologist, 56, 218-226.

Fry, P. S. (2000). Religious involvement, spirituality and personal meaning for life: Existential predictors of psychological wellbeing in community residing and institutional care elders. Aging \& Mental Health, 4(4), 375387.

Gençöz, T. (2000). Pozitif ve Negatif Duygu Ölçeği: Geçerlik ve güvenirlik çalışması. Türk Psikoloji Dergisi, 15(46), 19-26.

Halama, P. (2005). Relationship between meaning in life and the big five personality traits in young adults and the elderly. Studia Psychologica, 47, 167-178.
Halama, P., \& Dedova, M. (2007). Meaning in life and hope as predictors of positive mental health: Do they explain residual variance not predicted by personality traits? Studia Psychologica, 49, 191-200.

Henningsgaard, J. M., \& Arnau, R. C. (2008). Relationships between religiosity, spirituality, and personality: A multivariate analysis. Personality \& Individual Differences, 45, 703-708.

Hicks, J. A., \& King, L. A. (2007). Meaning in life and seeing the big picture: Positive affect and global focus. Cognition and Emotion, 21(7), 1577-1584.

Isen, A. M. (1999). On the relation between affect and creative problem solving. In S. R. Russ (Ed.), Affect, creative experience, and psychological adjustment (pp. 3-17). Philadelphia: Taylor \& Francis.

Jia-yan, P., Wong, D., Joubert, L., Lai, C., \& Wan, C. (2007). Acculturative stressor and meaning of life as predictors of negative affect in acculturation: A cross-cultural comparative study between Chinese international students in Australia and Hong Kong. Australian \& New Zealand Journal of Psychiatry, 41(9), 740-750.

Joiner, T. E., Catanzaro, S. J., \& Laurent, J. (1996). Tripartite structure of positive and negative affect, depression, and anxiety in child and adolescent psychiatric inpatients. Journal of Abnormal Psychology, 105, 401-409.

Kashdan, T. B., \& Steger, M. F. (2007). Curiosity and pathways to well-being and meaning in life: Traits, states, and everyday behaviors. Motivation \& Emotion, 31, 159-173.

King, L. A., \& Hicks, J. A. (2009). The detection and construction of meaning in life events. Journal of Positive Psychology, 4, 317-330.

King, L. A., Hicks, J. A., Krull, J., \& Del Gaiso, A. (2006). Positive affect and the experience of meaning in life. Journal of Personality and Social Psychology, 90, 179-196.

King, L. A., Richards, J. H., \& Stemmerich, E. (1998). Daily goals, life goals, and worst fears: Means, ends, and subjective well-being. Journal of Personality, 65, 713-44.

Klinger, E. (1977) Meaning and void--inner experience and incentives in people's lives. Minneapolis: University of Minnesota Press.

Lavigne, K. M., Hofman, S., Ring, A. J., Ryder, A. G., \& Woodward, T. S. (2013). The personality of meaning in life: Associations between dimensions of life meaning and the Big Five. The Journal of Positive Psychology, 8(1), 34-43.

Maddi, S. R. (1970). The search for meaning. In W. J. Arnold \& M. M. Page (Eds.), The Nebraska Symposium on Motivation (pp. 134-183). Lincoln, NE: University of Nebraska Press.

Mascaro, N., \& Rosen, D. H. (2005). Existential meaning's role in the enhancement of hope and prevention of depressive symptoms. Journal of Personality, 73(4), 9851013.

Moomal, Z. (1999). The relationship between meaning in life and mental well-being. South African Journal of Psychology, 29(1), 42-49.

Pan, J., Wong, D., Joubert, L., \& Chan, C. (2007). Acculturative stressor and meaning of life as predictors of negative affect in acculturation: A cross-cultural comparative study between Chinese international students in Australia and Hong Kong. Australian and New Zealand Journal of Psychiatry, 41, 740-750.

Park, C. L. (2010). Making sense of the meaning literature: An integrative review of meaning making and its effects on adjustment to stressful life events. Psychological Bulletin, 136, 257-301. 
Park, N., Peterson, C., \& Ruch, W. (2009). Orientation to happiness: National comparisons. Journal of Positive Psychology, 4, 273-279.

Peterson, C., \& Seligman, M. E. (2004). Character strengths and virtues. New York, NY: Oxford University Press.

Prager, E. (1997a). Meaning in later life: An organizing theme for gerontological curriculum design. Educational Gerontology, 23, 1-13.

Prager, E. (1997b). Sources of personal meaning for older and younger Australian and Israeli women: Profiles and comparisons. Ageing and Society, 17, 167-189.

Reker, G. T., \& Fry, P. S. (2003). Factor structure and invariance of personal meaning measures in cohorts of younger and older adults. Personality and Individual Differences, 35, 977-993.

Ruffin, J. (1984). The anxiety of meaninglessness. Journal of Counseling and Development, 63(1), 40-42.

Schnell, T., \& Becker, P. (2006). Personality and meaning in life. Personality and Individual Differences, 41, 117-129.

Schwarz, N., \& Clore, G. L. (1996). Feelings as phenomenal experiences. In E. T. Higgins \& A. Kruglanski (Eds.), Social psychology: Handbook of basic principles (pp. 433-465). New York, NY: Guilford Press.

Schwarz, N., \& Strack, F. (1999). Reports of subjective wellbeing: Judgmental processes and their methodological implications. In D. Kahneman, E. Diener, \& N. Schwarz (Eds.), Wellbeing: The foundations of hedonic psychology (pp. 61-84). New York, NY: Russell-Sage.

Steger, M. F. (2009). Meaning of life. In Lopez, S. J., \& Snyder, C. R. (Eds.), Oxford handbook of positive psychology (2nd ed., pp. 679-687). New York, NY: Oxford University Press.

Steger, M. F., Frazier, P., Oishi, S., \& Kaler, M. (2006). The Meaning in Life Questionnaire: Assessing the presence of and search for meaning in life. Journal of Counseling Psychology, 53, 80-93.

Steger, M. F., Kashdan, T. B., Sullivan B. A., \& Lorentz, D. (2008). Understanding the search for meaning in life: Personality, cognitive style, and the dynamic between seeking and experiencing meaning. Journal of Personality, 76(2), 199-228.
Steger, M. F., Pickering, N. K., Adams, E., Burnett, J., Shin, J. Y., Dik, B. J., \& Stauner, N. (2010). The quest for meaning: Religious affiliation differences in the correlates of religious quest and search for meaning in life. Psychology of Religion and Spirituality, 2(4), 206-226.

Şahin, M., Aydın, B., Sarı, S. V., Kaya, S., \& Pala, H. (2012). Öznel iyi oluşu açıklamada umut ve yaşamda anlamın rolü. Kastamonu Ĕ̆itim Dergisi, 20(3), 827-836.

Terzi, Ş. (2013, June). Meaning in life in Turkish cultural context. Paper presented at the International Conference on New Horizons in Education, Roma, Italy.

Terzi, Ş., Ergüner Tekinalp, B., \& Leuwerke, W. (2011). Yaşamda Anlam Ölçeğinin çeşitli yaş gruplarına göre psikometrik özelliklerinin değerlendirilmesi. In XI. Ulusal Psikolojik Danışma ve Rehberlik Kongresi (pp. 425-426). İzmir: Ege Üniversitesi.

Watson, D. (1988). Intraindividual and interindividual analyses of positive and negative affect: Their relation to health complaints, perceived stress, and daily activities. Journal of Personality and Social Psychology, 54(6), 10201030.

Watson, D., \& Pennebaker, J. W. (1989). Health compliments, stress, and distress: Exploring the central role of negative affectivity. Psychological Review, 96(2), 234-254.

Watson, D., Clark, L. A., \& Tellegen, A. (1988). Development and validation of brief measure of positive and negative affect: The PANAS Scale. Journal of Personality and Social Psychology, 54, 1063-1070.

Westerhof, G. J., \& Bohlmeijer, E. (2004). In search of meaning: A reminiscence program for older persons. Educational Gerontology, 30, 751-766.

Wong, P. T. P. (2010). Meaning therapy: An integrative and positive existential psychotherapy. Journal of Contemporary Psychotherapy, 40, 85-94.

Yalom, I. (1980). Existential psychotherapy. New York, NY: Basic Books.

Zika, S., \& Chamberlain, K. (1992). On the relation between meaning in life and psychological well-being. British Journal of Psychology, 83, 133-145. 